\title{
GENDER AND RACE DIFFERENCES IN CRIMINAL JUSTICE PROCESSING*†
}

\author{
ROSEMARY C. SARRI \\ University of Michigan, Ann Arbor, MI 48109, U.S.A
}

\begin{abstract}
Symopels-The importance of gender and race as critical vanables in criminal justice system processing is highlighted in this article These processes influence women and minority racial groups as victims and as offenders. The article addresses the situation in the United States between 1970 and 1985 pnmarily, but the focus on gender and race has application to many other countries

Followng a bnef historical assessment of the processing of black and white females, characteristics of female offenders are examined. Analysis of court processing highlights sex differences in pleas, bargauning, and sentencing The expenence of sentencing reform in one state is examined, followed by a report of the commitment and incarceration of women in one state over a ten-year interval These findings support the conclusion that gender and race must be analysed as cntical independent and intervening variables in studies of arrest, court processing, sentencing, and incarceration.
\end{abstract}

Reports about changes in female roles in US society appear to have had a significant impact on judges' and prosecutors' decisions because the incarceration of adult women has grown rapidly in recent years, despite the lack of evidence that there has been any substantial increase in senous crime by females (Steffensmeier, 1978; Steffensmeier et al., 1977; Figueira-McDonough, 1980). It seems quite clear that gender and race differences in crime and criminal justice processing shape the experience of women both as victims and as offenders. Gender is a critical variable in criminal justice processing in the United States, but attention must also be directed to race because there are substantial differences in the processing of non-white females.

\section{HISTORICAL PERSPECTIVE}

In the midst of current interest in the female offender, it is easy to forget that this offender is really not a new phenomenon While she has existed (albeit in smaller numbers) historically, she was generally regarded as incidental to the study of male criminality. Rising incarceration rates in many 1984.

- This article states the law as it stood at December

+ Earher versions of this paper were presented at the National Association of Social Workers Symposium in Washington, DC, 20 November 1983 and at the National Conference on Women Offenders at the Institute of Criminology, Canberra ACT, Australia, 12 June 1984. countries, however, refiected changes in the nature and incidence of crime among women and/or changes in the criminal justice system's response to her. The 'new' female offender in the United States has posed a challenge to these long and widely held assumptions:

(a) that the criminal justice system protected most women from the harshness of incarceration, and

(b) that female criminality was really black female criminality.

These assumptions were firmly entrenched as early as 1900 when Kellor wrote:

'There is no problem of criminality among white women of the South. In the cities there are but small numbers of workhouses [where female offenders served time], and the average is less then three each in the eight state institutions . . . . Laws are not enforced against women, even to the degree in the North. They are often pardoned when convicted, because of the harshness of the penal system . . . . But the facts for negro women are very different and conditions are such that they cannot well avoid immorality and crimlnality.' (537-538).

Analyses of official statistics, arrest data, and prison populations often mirrored support for these assumptions

Explanations offered for the relatively few nonminority women who encountered the criminal 
justice system were usually couched in intrapsychic terms An example of this position is mirrored by Bryan as early 1918 in her study of women at a house of correction (Bryan, 1953). She wrote that women were committed because of internal factors making for personal maladjustment. Explanations offered for black female criminality, however, deal with cultural and other environmental conditions In 1904, Dubois pointed to lax social norms in the black community as contributing to the high arrest rate among black women Arrest figures for Atlanta, for example, showed that, in 1900, 2086 black women were arrested as compared to 474 white women (Dubois, 1904)

Historically, black women have been overrepresented among prison populations. In 1890, when black women comprised only 14 per cent of the female population in the United States, they made up almost half (1989) of the total prisoner population (4304) In addition, it was not unusual for black female commitments to surpass those of white females. For example, in 1923, 6399 black women were committed to prison from 1 January to 30 June as compared with 5030 white women (Iglehart, 1977)

Several researchers pointed to differential processing as accounting for the seemingly high crime rate among black women. In a study of women offenders at a New York State Workhouse, Fernald et al. (1920) observed that the larger proportion of black women in the workhouse was probably due to the practice of giving workhouse terms to first or second offenders who might, if they had been white, have been given a chance on probation. More recently, numerous scholars achnowledge that black women have never been afforded 'protection' from the criminal justice system as had the non-minority women. Klein (1973) asserts that chivalry has never been extended to women of colour

In addition to being overrepresented in the criminal justice system, black women have been viewed as more criminal than the non-minority female. 'More criminal' referees to the tendency for black women to engage in more senous offenses Again, historical data support this difference Census data on prison populations from 1890 to 1936 show that a higher percentage of black women committed crimes against property and person than did white women A larger percentage of white women were involved in sex offenses, disorderly conduct, and drunkenness.

Instıtutional commitment patterns from 1900 to 1923 also show different patterns for white and black women White women were more likely to be found in county jails and workhouses while black women were more likely to serve time in state prisons and penitentianes Because large percentages of the commitments for senous offenses were to state facilities (US Department of Commerce, 1926: 32), it was said that black women were, no doubt, sentenced in accordance with the type of crimes they committed.

As early as 1904, sentencing was observed for these two groups of women. Of the black women sentenced, almost half recelved a year or more of confinement For white women, however, a little over half served less than one year Of course, length of time served should be reflective of the degree of senousness of the crime committed, but as noted later, that is often not the case

Regardless of the theories of causation, black females are more likely than their white counterparts to be arrested, charged, convicted, and sentenced to prison These trends have existed since the first years official statistics were recorded Tables 1 and 2 are illustrative of the gap between black and white women in arrest rates and incarceration rates In 1940, for the State of New York, 181 black women were arrested per 100,000 in

Table 1 Arrest ratıos per 100,000 persons in the general population, according to sex and race, New York State (1940)

\begin{tabular}{lc}
\hline Sex and race & Ratıo \\
\hline White female & 117 \\
Black female & 1811 \\
White male & 2635 \\
Black male & 18903 \\
\hline
\end{tabular}

Source Pollak (1950 116)

Table 2 Ratios of prisoners received from courts by state and federal prisons, per 100,000 in the United States (1940 and 1980)

\begin{tabular}{lrr}
\hline Sex and race & $\begin{array}{r}\text { Ratios } \\
(1940)\end{array}$ & $\begin{array}{r}\text { Ratıos } \\
(1980)\end{array}$ \\
\hline White female & 36 & 6 \\
Black female & 209 & 47 \\
White male & 953 & 178 \\
Black male & 3847 & 1148 \\
\hline
\end{tabular}

Source U S Dept of Justice Bureau of Statistics, Prisoners in State and Federal Institutions on 12/31/80 P 21, and Pollak (1950 117)

New York. The rate for white women was 12 Black women were more likely to be processed through the criminal justice system from arrest to imprisonment than were white women: the incarceration rate for black women was 21 as compared to 4 for white women Rates from 1932 to 1936 for the United 
States support these gaps. For this period, white women had an incarceration rate of 6 per 100,000 while black women had a rate of 21 (von Hentig, 1948: 236) By 1980 these ratios had changed substantially, producing even greater racial differences.

Pollak (1950: 115) summarized three major opınıons on the race factor in female criminality: first, black women are thought to be more criminal than white women; secondly, they are believed to surpass the criminality of white women to a greater degree than black men seem to surpass the criminality of white men; and thirdly, their criminality appears to come closer to the criminality of black men than the criminality of white women does with regard to that of white men. More recent attention on female criminality has acknowledged the special case of the black female offender while moving on to explain the causes of the recent rise in crime rates among non-minority women Theories of changing opportunity structures and women's liberation ignore the fact that the women most likely to be processed through the criminal justice system are the least likely to respond to ideologies of sexrole equality. In 1934, Sheldon and Eleanor Glueck studied five hundred delinquent women and wrote. 'The women are themselves on the whole a sorry lot' (p. 299). Today, the lot of female offenders seems to have worsened. While black women are still overrepresented, it is apparent that factors that give rise to female offenders are stronger than ever before.

\section{WHO ARE THE FEMALE OFFENDERS}

Self-report surveys of offenders (Short and Nye, 1970) indicate that the vast majority of adults have committed one or more misdemeanors or felonies, but the prevalence and frequency of crime is far less for females than males. Only in the case of larceny, drug use and abuse, forgery, fraud, and sex crimes do females commit with equal frequency. Only 10 per cent of those arrested for all types of person crimes in 1980 were female, but in the case of larceny, 29 per cent were female The findings in Table 3 reveal an overall male/female sex ratio of 5.3 in 1980 , but the ratio for person crime is far higher (9.2) than for property crime (3.7)

In a longitudinal study of female criminal behavior Steffensmeier et al (1977) concluded that for violent crime the female profile was essentially similar to that in 1960 . However, they observed that there had been increases in larceny, fraud, and forgery, and in vagrancy and disorderly conduct Females made few gains in traditional 'male' crimes. They also indicated that reporting patterns need careful examination because they vary over time, by
Table 3. Index cnmes (arrests) by sex (1980)

\begin{tabular}{lccc}
\hline & & \multicolumn{2}{c}{ Criminal arrests } \\
Sex & Person* & Property $\dagger$ & Total \\
\hline Male & 401,589 & $1,383,350$ & $1,784,939$ \\
Female & 44,784 & 368,354 & 413,138 \\
Sex ratio $\ddagger$ & 92 & 37 & 5.3 \\
\hline
\end{tabular}

* Person crimes include murder, manslaughter, robbery, aggravated assault.

+ Property cnmes include larceny, burglary, auto theft

$\ddagger$ Sex ratio $=$ male arrests/female arrests

Source U.S. Dept of Justice, FBI, Uniform Crime Report, October $1981 \quad 24-27$

geographical area, and by organizational attributes of processing agencies. For example, women are viewed less paternalistically today and, therefore, may not be dismissed or 'filtered out' of official processing as they may have been in the past (Steffensmeier, 1980).

Prostitution and promiscuity are behaviors for which women are almost exclusively prosecuted today. But this has not always been the case, as Hewitt and Mickish recently noted (1983). They examined the official handling of prostitution in Muncie, Indiana, between 1900 and 1920 and observed that there were nearly equal numbers of males and females arrested, tried, and convicted for prostrtution. Then, in the 1920 s laws and practices began to change, illustrating the fact that deviance occurs in the context of social institutions that have the power to label some persons as deviants and other not so. The sexual status attributed to female deviance is also evident in the assumptions made by official agents that all female deviants are sexually deviant (Chesney-Lind, 1977).

Those who have argued that, with increased opportunity for women in the labor force, there would be an increase in occupationally related crime have found few data to support their assumptions. Most women remain in low-paid, sex-segregated occupations. Female crime continues to be attributed to female sex roles, whereas male crime is usually attributed to social structural features, Feminist perspectives on crime and gender assume a broader perspective than do traditional social science perspectives The latter generally are interested only in who committed the crime, whereas feminists view the crime within a wholistic conception of social power, gender relations, and economic stratification. They are as interested in the crimes committed against women as in those by women

\section{COURT PROCESSING}

Examination of gender patterns in court processing is particularly important, and many research 
findings have pointed to substantial differences. In a study of processing in Washington, DC, FigueiraMcDonough (1982) observed marked male/female differences in the processing of larceny, drug, and sex crimes There were few differences in the treatment of person and serious property crime. She noted that those who argue that men and women are treated similarly are accurate when discussing crimes in which males predominated. But, if one examınes crimes where females predominate, there are large differences in treatment in plea bargaining, in rates of guilty pleas, and in sentence bargaining. Women were less able to bargain effectively and were more often willing to plead guilty to the onginal charge. They were less likely to have their charges reduced during the plea-process and they fared less well in sentencing bargaining.

Figueira-McDonough also found that senousness of offense and prior record were weaker predictors of sentences for females. Although males overall received stiffer sentences, the reverse was true for larceny where females predominated. In fact, controlling for pnor record, race, and residence, the probability of severe sentences for larceny and sex crimes for women was nearly the same as for violent offenses. Family and friendship ties to the victim predicted to the incarceration of females, but the opposite was true for males. ${ }^{1}$ Figueira-McDonough (1982) also examined processes of charge bargaining and sentence reduction and observed differential treatment and outcomes for females when compared with males. Females plead guilty more often although they have fewer continuances; they commit less serious crime; and they receive fewer charge or sentence reductions regardless of how they plead.

In a similar study in two midwestern cities Butler and Lambert (1983) observed that the treatment of males and females vaned markedly between the two courts. Seriousness of the offense, past record, race and type of pleas were better predictors of male outcomes than for females They concluded that incapacitation models were better predictors for males, whereas treatment rehabilitation models more often appeared to influence judicial decisionmaking for females.

Processing patterns for juvenule offenders manifest similar gender differences. Despite the passage of the Federal Juvenile Justice and Delinquency Prevention Act, female delinquents continue to be processed more often for non-criminal offenses than do males Sexual and moral misbehaviours are

\footnotetext{
${ }^{1}$ Friendship ties to the victım refer primarily to instances where the offender was a relative or close acquaintance of the victim In the case of senous person crime by females, very frequently the victim is a spouse or child of the offender
}

judged as more senous offenses for females. For criminal offenses, there are fewer differences, but males may be dealt with more punitively-especially with respect to incarceration.

\section{GENDER AND SENTENCING REFORM}

Before examining the umpact of sentencing reforms through the use of sentencing guidelines, it is essential to emphasize our particular concern with gender as an important variable when considering sentencing reform, including the application of sentencing guidelines. Most of the writers ignore gender as a variable worthy of consideration (Gottfredson and Gottfredson, 1980). Only Kay Knapp in her reports on evaluation of the implementation of the Minnesota Guidelines even mentions findings about gender similarities or differences (Knapp, 1982). Others proceed to develop gurdelines on the characteristics of the majority male offender, failing to note that criminal behavior patterns of women differ significantly.

It is also umportant to consider gender because research findings about discrimination and disparity in the sentencing of females, as compared with males, remain contradictory and do not permit firm generalizations. Some findings indicate that courts are more lenient in the processing, conviction, and sentencing of females. Others state just the opposite while a third group argues that one must control for type of offense, pnor offense record, presence of dependent children, and adequacy of defense counsel.

In a case record study of defendants convicted of theft, forgery and fraud, and drug violations in an urban midwestern county, Krutschnitt (1981) observed that, overall, females appeared to have a slight advantage in terms of leniency of the sentence received, but she was unable to control fully for variations in offense, offense history, and processing experience. She did observe sex- and race-linked discrepancies in that non-white males and older females were significantly more likely to receive harsher sanctions regardless of controls. Perhaps even more important was the fact that few predictors had a consistent effect across sentencing decisions.

Zalman et al. (1979) analysed a state-wide sample of sentencing decisions and observed substantial vanation among judges which could not be explained by offense or offense-related characteristics. They observed that non-whites received harsher sentences for homicide, assault, robbery, sex, burglary, and larceny crimes Moreover, they also observed that non-whites recelved longer sentences for burglary, sex, drug, and larceny offenses Unfortunately, no systematic comparisons were made of race and sex. Zalman recommends the 
development of presumptive sentencing guidelines and statewide review as the more promising politics for reducing judicial disparity.

Daly (1981) argues that both class and gender must be carefully examined if one is to understand differences in criminal court processing and outcomes. She notes that women more often appear to receive less harsh criminal justice sanctions than do men, but such findings can be misleading if comparisons are made only between females and males and not within groups of each. She also suggests that feminist theory of 'patriarchy' can be used to specify how defendants' form and degree of 'family connectedness' become critical dimensions in court adjudication. Court agents expect women to perform family labor, to be responsible for children, and they recognize that labor is important to the maintenance of family life. As a corollary, court agents expect that men will be the primary breadwinners. They also assume that the heterosexual marital state is a stable group so long as men and women have mutual responsibilities therein. Bernstein's findings confirm the importance of this perspective on male-female roles (Bernstein et al., 1979)

Given this perspective, controls must be applied for family responsibility and dependence, prior criminal record, seriousness of the crime committed, and adequacy of the counsel provided to or for females as well as males, despite the fact that the former commit far less serious crime Too often it is assumed that defense counsel is unnecessary for minor crimes.

\section{SENTENCING GUIDELINES}

As of 1983 only three states had established statewide sentencing gundelines with specific recommendations on in/out decisions and on the length of a prison term for a given offender and offense. These are: Utah (1979); Minnesota (1980); and Pennsylvania (1982). In Minnesota and Pennsylvanıa, guidelines have been enacted by the state legislature, and in Utah they have been formulated as administrative policy, by the state court. These guidelines have as their purpose the establishment of rational and consistent sentencing standards which reduce sentence disparity and ensure that sanctions are proportional to the severity of the offense of conviction and the extent of the offender's criminal history.

Sentencing guidelines are being developed and umplemented in an additional six states. Maryland, Massachusetts, Rhode Island, Vermont, Washington and Wisconsin Numerous local jurisdictions also utilize sentencing guidelunes. Denver, Chrago, Newark and Phoenix (Kress, 1980).

Because there has been ongoing monitoring and evaluation by the state Sentencing Gudelines
Commission, it is possible to ascertain some of the impact that occurred during the first two years of operation on a state wide basis of the guidelines implemented in Minnesota. The Minnesota Guidelines explicitly state that the following principles are to be adhered to in sentencing:

(1) Sentencing should be neutral with respect to race, gender, social or economic status of convicted felons.

(2) Commitment to the Commissioner of Corrections is the most severe sanction, but the policy must provide for increasing severity of sanctions proportional to the severity of offenses and criminal history

(3) Because the capacities of correctional facilities are finite, use of incarceration should be limited to the more serious felonies and for those with long criminal histories. Sanctions should be the least restrietive type necessary to achieve the purposes of the sentence.

(4) Guidelines are available to the sentencing judge, but there should be departures from the presumptive sentences only when substantial and compelling circumstances exist.

The guidelines are a part of an overall sentencing structure created by the Minnesota legislature in 1980. This structure incorporates certainty of sentence, accountability in sentencing, truth in sentencing, appellate review of trial court sentencing practices, an elaborate monitoring system, and a process for review and modification of the guidelines.

The range and form of the sentence can vary widely between the states. In the case of Minnesota, a non-imprisonment alternative is recommended for most property crimes in which the offender does not have an extensive criminal history. In contrast, in Pennsylvania non-confinement is specified only for misdemeanors with mitigating circumstances Judges in Pennsylvania have far broader discretion, but in both instances, judges who depart from the guidelines must provide written explanations as to why they did so.

Minnesota has had a longstanding interest in controlling prison populations; therefore, the sentencing gudelines were viewed as an important mechanism in aiding this control. Minnesota had passed the Community Corrections Act 1974 to foster community corrections by providing state subsidies to participating counties for the development of alternatives to state imprisonment.

Pnor to the implementation of the guidehnes, data of female/male sentencing in Minnesota indicated clearly that women were convicted of far less senous crimes than were men (Table 4).

Examination of sentences indicated that 20 per 
Table 4 Convictions, by offense in Minnesota (1979)

\begin{tabular}{lcc}
\hline Offense & $\begin{array}{c}\text { Male } \\
\text { (per cent) }\end{array}$ & $\begin{array}{c}\text { Female } \\
\text { (per cent) }\end{array}$ \\
\hline Persons crimes & 19 & 7 \\
Senous property & 19 & 3 \\
Non-senous property & 41 & 70 \\
Victimless & 17 & 15 \\
Other & 4 & 5 \\
$N$ & $(1774)$ & $(491)$ \\
\hline
\end{tabular}

Source: Minnesota Dept of Corrections Annual Report, 1979

Data were taken from the 1979 Annual Report, but were recorded and analysed to obtain the above information

cent of females and 29 per cent of males were sentenced to prison-clearly disparate sentences for females, given their conviction offense. In addition, examination of criminal history revealed even more discrepant results for 65 per cent of the females had no prior offense record, whereas only 46 per cent of the males had no prior record. Further disparity is evident in the length of sentences handed down, as Table 5 indicates

Table 5. Sentence midpoints, in years, in Minnesota (1979)

\begin{tabular}{lcc}
\hline Midpoint & $\begin{array}{c}\text { Male } \\
\text { (per cent) }\end{array}$ & $\begin{array}{c}\text { Female } \\
\text { (per cent) }\end{array}$ \\
\hline Less than one year & 18 & 10 \\
1-2 years & 53 & 56 \\
3-4 years & 1 & 1 \\
5 years & 18 & 30 \\
More then 5 years & 10 & 3 \\
$N$ & $(1775)$ & $(513)$ \\
\hline
\end{tabular}

Source. Minnesota Dept of Corrections Annual Report, 1979

Women were more likely to receive probation sentences than were men, but the length of that sanction was far longer on average and highly disparate if one considered offense seriousness. Not surprisingly, 65 per cent of the women had minor dependents as contrasted with 33 per cent of the men. Women with minor children were more likely to recerve a sentence to probation (albeit longer) than were other female and male offenders. No significant male/female differences were observed in residence, education, occupation, except that females were more likely to have had a shorter and more disruptive employment history and were less likely to be employed at the time of commitment of the offense or at sentencing.

In 1982 the first $\mathbf{5 5 0 0}$ cases sentenced under the Minnesota guidelines were evaluated compared to a baseline group of 4369 cases sentenced in 1978 (Minnesota Sentencıng Guidelınes Commission, 1983) ${ }^{2}$ The findings revealed: ${ }^{3}$

(1) Sentencing practices substantially conformed to the policy articulated in the guidelines. There was a 73 per cent increase in the imprisonment of offenders convicted of high severity crimes with low crimunal histories and a 72 per cent reduction in the imprisonment of offenders convicted of low severity crimes with moderate to high criminal histories. Between 90 and 95 per cent of the felony sentences imposed were presumptive sentences.

(2) Disparity in sentencing decreased with greater uniformity and proportionality. However minority offenders (Blacks and native Amer1cans) received somewhat more severe sanctuons than did whites, even when controlling for severity level and crimunal history. Most of this difference was attributable to two metropolitan counties which processed larger numbers of non-white offenders

(3) Prison populations remained stable in contrast to the sharp increases in other states at this tume Commitments were close to the projected level.

(4) The commitment rate for females declined to 5.5 per cent, considerably below the expected level of 9.2 per cent, but the rate for males also fell 1 per cent below the predicted level to 162 per cent The female prison population declined from 80 to 56 persons-again in sharp contrast to practices in surrounding states.

(5) Overall, the rate of trials did not increase and processing time remained nearly identical Fewer than 1 per cent of the presumptive sentences were appealed.

This information suggests that the sentencing guidelınes were relatively effective in achieving the stated goals for which they were enacted, at least in the first two years. However, when the Commission

\footnotetext{
2 For the baseline comparison a 50 per cent sample of 2332 cases was drawn from the total of 4369 convicted felony offenders in Minnesota in 1978

${ }^{3}$ For a full report of the intial evaluation of the implementation of the Minnesota determinate sentencing law and sentencing guidelınes see Minnesota Sentencing Gudelines Commission (1982) and Goodstein (1983)
} 
released it 1983 findings, some reversals and disturbing patterns emerged. Prison sentences were once again on the increase for both males and females. Several actions by the legislature and by law enforcement personnel have produced a dramatic increase:

(1) The commitment rate during the first two years was 15.0 per cent of those convicted, and that increased to 185 per cent during 1981-1982 despite the fact that the number of convictions also increased from 5500 to 6077 . This resulted in a 36 per cent increase in commitments by the end of 1982

(2) In 1981 the legislature increased mandatory minimum sentences for felonies committed with a handgun from one year to three years for the first offense and to five years for the second offense. Moreover, both prosecutors and judges received increased discretionary authority to negotiate the imposition of mandatory sentences

(3) Prosecutors dismissed fewer felony cases in the second period in a successful effort to build higher criminal history scores, and thereby require incarceration under provisions of the guidelines. The percentage of offenders with criminal history scores of four or more increased more than 50 per cent.

(4) Increasing numbers of property offenders, particularly females, were sent to prison in violation of the basic policy of the guidelines that person offenders should be committed to prison, not property offenders. Lower severity property crimes had particularly large rates of increase.

(5) There was an increase of 32.8 per cent of females against a 77 per cent increase in the commitment of males, but these increases were not related to convictions for more serious crimes Similarly, there was a 29.0 per cent increase in the commitment of blacks and only an 8.9 per cent increase in white commitments, and again it was not possible to link these differences to criminal behavior of the offenders.

(6) Parole and probation revocations increased as did revocation for stayed felony guideline cases where offenders were placed in the community rather than in prison. One metropolitan county contributed disproportionately to the revocations.

The Minnesota Commission is presently contınung its review process and makes recommendations to the legislature for action to mantain the thrust of the mandate which led to the establishment of the guidelines. One can only speculate about the reasons for the prosecutors and other criminal justice personnel operating to dramatically increase the numbers of persons convieted and the rate of commitment in the second two-year period. It is possible that they were influenced by the strong pressures for more punitive intervention in surrounding states, and as elected officials, they were also influenced by local opinion. Nonetheless, the inter-county differences are noteworthy as is the fact that these changes occurred during a time in which the crime rate overall was on the decline. The continued patterns of institutionalized racism and sexism provide support for Daly's (1982) propositions about the impact of gender, race and class on criminal justice decision-makng. The evaluation of the Minnesota sentencing reform by Goodstein (1982) highlights many of the actors and facets of the criminal justice system who resisted the implementation of this innovation in the first two-year penod

Minnesota also formulated a complete set of sentencing gudelines for juvenile offenders, but these have not as yet been enacted. Because status offences and other non-crimes are incorporated into these guidelines, it is probable that their implementation will contribute to the expansion of formal social control over more and more youth in the justice system.

\section{WOMEN IN CUSTODY}

Despite the discrimination or inequities that exist among police, judges and prosecutors, the most senous problems exist in residentral facilities: jails, reformatories, lockups and other facilities. As of mid-1983 the United States' prison population totalled 431,829 adults, and it was increasingly annually at a rate of 8.4 per cent (US Department of Justice, 1983) Including with this number the population of those in jails, juvenile detention and trainıng school facilities, the total census of incarcerated persons in criminal justice facilities in the United States would easily exceed 700,000 persons-and we have not even considered those in vanous types of lockups or those in mental health facilities for offenders. Given the likelihood that those presently in jail or juvenile facilities have a high probability of subsequent incarceration in an adult prison, there does not appear to be any likelihood of significantly reduced populations during the $1980 \mathrm{~s}$, at least. Moreover, prison construction in excess of two billion dollars is underway in 39 states. Declines in the available young adult population and in the crime rate appear not to have any real effect, because the vast majonty of states report higher rates of incarceration with 
little or no relation to the crime rate in the respective jurisdictions.

Amenca's prisons and jals had increasing and disproportionate numbers of non-whites during the 1970s and 1980s (US Department of Justice, 1971-1983). Approximately 50 per cent of all inmates in prisons and jails are non-white, but when rates per 100,000 are examined, discrepancies are revealed. Table 2 indicates that there is an overall prison incarceration rate of 145 , but the rate for whites is 178 and for blacks 567; for Hispanics, it is 164; and for native Americans, 212. Because ten states do not code Hispanics as a separate group, their rate represents a large undercount. When one examines the rates for females, greater racial discrepancies are noted. Overall, the female rate is 22 per 100,000-far below that for males, but for white women it is six and for black women, 47.

Although the United States has a long history of high rates of incarceration, the period from 1930 to 1970 was relatively stable. However, since the mid1970 s there has been a steady and substantial increase in prison populations-peaking at annual growth rates of 12 per cent in 1981 and 1982 Increases for females exceeded those for males because the female population increased by 133 per cent to 18,853 since 1974 and the male population increased by 86 per cent. Nonetheless, the female/male ratio did not change; females continue to occupy approximately 4 per cent of the prison beds in the United States.

What factors assist in understanding how and why these changes have occurred in the numbers of persons incarcerated? First, socio-demographic factors have been identified as key vanables because of the tremendous boom in the young adult population between the ages of 15 and 25 in the mid1970 s. Secondly, increasing numbers of immigrant and minority populations were eligible for prisonization-particularly because they have experienced severe economic and social discrimination. Thirdly, persistent economic recessions since 1973-1974 have permanently dislocated thousands of blue collar workers and young adults attempting to enter the labor force. These populations are particularly at risk for increased crime, and especially for increased incarceration given their lack of employment, as findings from the Vera Institute Manhattan Study indicated. Fourthly, penal code reform took place in many states and in most instances involved increasing the type, length, and severity of the sanctions imposed on convicted offenders. Fifthly, income inequality increased particularly for women and most of all for minority women who were single heads of households. The increasing feminization of poverty paralleled the rapid increase in the incarceration of women who were also disproportionately non-white, poor, unemployed, and head of households. It should also be noted that in this penod there were persistent efforts to reduce and control the amount of income allocation through the Aid to Families with Dependent Children (AFDC) program.

In Michigan, changes in the Incarceration of women over a ten year interval were examined (Figueira-McDonough et al., 1981). Between 1968 and 1978 that state experienced a 500 per cent increase in female offender commitments and an overall increase of 260 per cent in its female offender population in prison. In that same tıme interval, crime rates by women increased by less than 15 per cent. However in 1977 Michigan opened a new prison for women and the increasing availability of bed space appears to have been a major factor in judicial decision-making. Some of these findings should be highlighted because they lead to a greater understanding of the dramatic changes that have occurred in many states:

(1) There was a 368 per cent increase in the nonwhite population as compared with a 120 per cent increase in white female offenders in prison. The sharpest increase in non-whites occurred after 1974, a time of serious economic recession in Michigan. That recession had a very negative impact on non-white females employed in blue collar occupations.

(2) Although nearly 90 per cent of women had borne children, only 15 per cent were marned. Most encountered serious problems as single parent heads of households and moved to crime as one survival technique

(3) Offenders were senously educationally disadvantaged and that disadvantagement increased during the 1970 s as measured by standard test scores.

(4) Increases in alcohol and drug abuse or addiction were substantial as were increases in the percentage of offenders who had a history of mental illness and psychiatric placement.

(5) Women in prison overwhelmingly represent the working poor, but only about 30 per cent had received welfare support. The major changes which occurred during the period of this study were the declines in the occupational level and amount of labor force participation. By 1978, 53 per cent of those entering prison had no full-time occupation; 19 per cent were in unskilled occupations and 11 per cent were in service occupations. Fewer than 10 per cent were in professional or skilled occupations-a far cry from statements of some who assert that increased crime by females is associated with increased particlpation in the primary labor force (Simon and Adler, 1979). 
(6) It is often asserted that the offense behavior of females has changed, but our research found it not to be so. In 1967, five offenses accounted for three-fourths of all commitments: larceny, forgery, homicide, burglary, and assault, in order of their relative importance. Ten years later, larceny still was first at 31 per cent, followed by drug-related crimes (15 per cent); forgery and fraud (14 per cent); robbery (12 per cent); and homicide ( 7 per cent) There was no support for the argument that females have increased violent behavior.

(7) In contrast to adult male offenders, less than one-third of the women had a history of juvenile offending More than half had never served tume proor to the present commitment. The conceptualization of 'criminal career' found in much of the literature appears generally inapplicable with regard to female offenders

(8) Two thirds of all commitments received minimum sentences of two years or less, but during the decade the average sentence increased from 44 to 54 months There was a tendency for the average sentence to gravitate toward one to two years, regardless of offense. The average length of stay also increased; 54 per cent spent one year or longer in 1968 , and that increased to 74 per cent in 1978. When race was examined, it was observed that there were few differences, if one considered long sentences, but in the case of short sentences, non-whites predominated It appeared, however, that non-whites charged with larceny (especially shopliftıng) were sent to prison for short sentences, but their parallel white sisters remained in the community on probation.

\section{GENDER AND THE LIABILITY OF BEING BLACK AND YOUNG}

Throughout the United States, correction populations are disproportionately non-white and under the age of thirty. This pattern was also observed in Michigan, but this study revealed substantial differences for male and female offenders. Throughout the decade the percentage of non-white offenders grew throughout the prison population, but it grew faster for females. In 1972 the male prison population was 58 per cent non-white while the female population was 69 per cent non-white. In 1976 the non-white population had declined to 54 per cent while the female non-white population grew to 74 per cent.

With the accumulated evidence in this study that women committed to prison in this state were predominantly losers, it would appear that being black and female represents some form of double jeopardy reinforcing their loser status. Unemployment statustics for the state of Michigan (Michigan Employment Security Commssion, 1980) reinforce this assumption. Between 1960 and 1975 the female labour force participation increased from 40 to 45 per cent. However, while non-white women had a higher participation rate than white women in both 1960 and 1970, the reverse was true in 1975. That is, non-white women decreased their participation in the labor force during the severe recession of 1974-1975. More recent unemployment data lend further support to this interpretation. In 1976 woman had much higher unemployment rates than men, and non-white women had the highest unemployment of all groups. Even later in 1978 when employment rates increased substantially in Michigan, major gains were made by white males and the least by non-white females.

Female offenders were older on the average than were male offenders in Michigan's prisons (27 vs 22 years), but only 25 per cent of all female offenders in prison in Michigan were older than thirty. Similar to the above observation on race, unemployment data indicates clearly that this age group is disproportionately at risk as far as employment is concerned Thus, gender, age, and race interact to increase the probability of serious disadvantage in our complex and competitive society

The findings from this research about the changes in the commitment of women to prison in Michigan between 1968 and 1978 presents a bleak picture, but they do challenge many of the popular assertions that are frequently made about female offenders. They indicate quite conclusively that criminal behavior patterns of incarcerated females have changed very little in this decade. The findings also suggest that many of the theories and propositions about criminal behavior which are based on studies of males are often inapplicable to females. Because females concentrate their criminal behavior in different areas, do not follow the same 'career' patterns, and because they behave differently in the processing systems, we need to develop a distinct conceptualization of female crimınal behavior Similarly, greater knowledge is required about the vanable response of the male-dominated criminal justice system to female behavior and status.

Females committed in Michigan were largely nonwhite, under-educated, poor or from poor families, and unemployed or employed in low skill occupations Given their dependents and other family responsibilities, many of them may have dnfted to property crime to solve immediate problems, or to more senous person crime when stress became such that they were unable to respond appropriately. Institutionalized racism once again appeared to be a fundamental problem in the criminal justice system.

The other pattern that had stood out in this study 
of the commitment of female offenders to prison was the minimal use of community correctional intervention. As was noted earlier, two-thirds of these women had no record of contact with the juvenile justice system and more than half had never served time prior to the present commitment. Nearly three-fourths ( 71 per cent) were committed for a property or victimless rather than a person crime. Thus, one inevitably must ask the question why they were sent to prison in the first place. The vast majority certainly were no threat to the public's safety. Moreover, being in prison inevitably compounded their problems with respect to their children and families, to employment, and to their own personal well-being. The increased evidence of mental illness and serious substance abuse in this population cannot go unnoticed. But, prison programs in Michigan, as in other states, provided no effective treatment for these problems.

\section{CONCLUSIONS}

By examining some research findings on court processing, sentencing, and incarceration from a gender and race perspective, the utility of such an approach in increasing our understanding of the operation of the criminal justice system is demonstrated. Clearly there are numerous implications for law, policy, and programs for females as well as males, but this demonstrates that changes specific to women must be addressed. Feminist perspectives argue that crime occurs in the context of class, race, and gender relations. An adequate understanding of crime and deviance requires analysis of the ways in which institutionalized patterns of gender and race influence the behaviour of both women and men

This article does not address the broader issues confronting this society with respect to poverty, unemployment and insecurity In the past few years we have expenenced senous structural crises brought on by economic recession and federal changes in social welfare policies and programs. The feminization of poverty is a reality to milhons of women and children and it will undoubtedly influence the criminal justice system, if past history provides any gunde. Whether recognition of the problems will produce ad hoc responses or a sound reassessment and the establishment of more comprehensive social policies is highly uncertan today

\section{REFERENCES}

Bernstein. Irene. John Cardascia and C E Ross 1979 Defendant's sex and crimınal court decisıon In Alvarez. $R$ and $K$ G Lutterman. eds. pp 329-354 Discriminathon in Organizations Jossey Bass, San Francisco Bryan, H. 1953 Inside Houghton-Mifflin, Boston Butler, Amy and Sue Lambert 1983 Examıning sentencing models for two midwestern courts: gender differences. University of Michigan Institute for Social Research, Ann Arbor. Paper presented at the Annual Meeting of the American Criminology Society, 11 November 1983, Denver, Colorado

Chesney-Lind, M. 1977 Judicial paternalısm and the female offender Crume and Deliquency (23 April) 121-130.

Daly, Kathleen 1981 Gender differences in criminal court outcome: towards a theoretical formulation linking class and gender relations. Department of Sociology, Amherst MA. Paper dehvered at the Amencan Cruminology Society Annual Meetıng, November, Washington, DC

Datesman, Susan, Frank Scarpitt and Robert H Stephenson. 1975 Female delinquency: an application of self and opportunity theories $J$ Res Crume Deliquency 12 (July): 107-123

Dubois, William E. B. 1904. Some Notes on Negro Crime. Atlanta University Press, Atlanta, GA

Fernald, M., M. H Hayes and A Dawley. 1920 A Study of Women Delinquents in New York State 1968 edn Patterson Smith, Montclair, N.J

Figueira-McDonough, Josefina 1980 A reformulatıon of the 'Equal Opportunity' explanation of female delınquency Crime and Deliquency 26 (3 July) 333-341

Figueira-McDonough, Josefina 1982 Gender differences in informal processing a look at charge bargaining and sentence reeducation in Washington DC Institute for Soctal Research, Ann Arbor Paper presented at the Annual Meeting of the Amencan Cnminology Society Annual Meeting, November 1982, Toronto, Ont

Figueira-McDonough, Josefina, Rosemary Sarr and Alfreda Iglehart 1981 Women in Prison in Michigan 1968-1978 A study of Commutment Patterns Instutute for Social Research, University of Michigan, Ann Arbor, MI

Glueck, Eleanor and Sheldan Glueck 1934 Five Hundred Delinquent Girls Alfred Knopf, New York.

Goodstein, Louse 1982 Sentencing reform and the correctional system. a case study of the implementation of Minnesota's determinate sentencing law Paper presented at the Annual Meeting of the American Criminology Association, (9-13 November), Denver, $\mathrm{CO}$

Gottfredson, Michael $\mathbf{R}$ and Donald $M$ Gottfredson 1980 Deciston-making in Criminal Justice Toward the Rational Exercise of Discretion Ballinger. Cambridge. MA

Hewitt, John D and John E Mickish 1983 The legal control of female sexual behavior dunng the progressive era a local history Ball State Unuversity, Department of Criminal Justıce, Muncie. IN Paper presented at the Annual Meeting of the American Criminology Society Annual Meeting, 12 November, Denver, $\mathrm{CO}$

Iglehart, Alfreda 1977 Differences in black and white female crimınality Unpublıshed paper (March 1977) University of Michigan School of Social Work. Ann Arbor, Ml

Kellor, Frances 1900 Psychological and environmental study of women criminals Am J Sociology 5 527-543

Klein, Dorie 1973 The etiology of female crime Issues in criminology 8(2) 3-30

Knapp, Kay 1982 Impact of the Minnesota sentencing gudelines in sentencing practices Hamline Law Rev 
5(2) $237-256$

Kress, John M 1980 Prescription for Justice The Theory and Practice of Sentencing Guidelines Ballinger, Cambridge, MA

Krutschnitt, Candy 1981 A Nature-Nurture Controversy Attempting to Understand the Relationship Between Sex and Severity of Disposition. Department of Sociology, Minneapolis, MN

Michigan Employment Securities Commission 1980 Uemployment Statistics 1978, 1979 Michigan Department of Labor, Lansing, MI

Minnesota Sentencing Guidelines Commission 1983 1981-1982 Sentencing Practices Preltminary Analysis MGSC (4 March) St Paul, MN

Pollak, Otto. 1950 The Criminalty of Women Unıversity of Pennsylvanıa Press, Phıladelphia, PA

Rasche, Christopher F 1974 The female offender as an object of criminological research Criminal Justice and Behavior I. 301-302

Short, James and Fred Nye 1970 Extent of unrecorded juvenile delinquency in Teele, J E, ed, Juvenile Delinquency Reader FE Peacock, Ithaca, IL.

Simon, Rita and Freda Adler 1979. The Criminality of Deviant Women Houghton Mifflin and Co, Boston.

Smart, Carol. 1977 Women, Crime and Criminology Routledge and Kegan Paul, London

Steffensmeier, Daniel 1978 Crime and the contemporary woman an analysis of changing levels of female property crime, 1960-1975 Social Forces 57(2) 566-
584

Steffensmeier, Daniel 1980 Assessing the impact of the women's movement on sex-based differences in the handling of adult criminal defendants Crime and Delinquency 26 (3 July) 333-343

Steffensmeier, Danıel, R. Steffensmeier and A. Rosenthal 1977 Violence and the contemporary woman an analysis of changing levels of female volence, 1960 1974 Paper presented at the Annual Meeting (August) of the American Sociological Association, Chicago, IL

US Department of Commerce, Bureau of the Census 1926 Prusoners in State and Federal Institutions US Government Printıng Office, Washington DC

US Department of Justice, FBI 1983 Uniform Crime Reports (October) Government Prunting Office, Washington, DC

von Hentig, Hans. 1948 The Criminal and His Victum Studies in the Sociology of Crime Yale University Press, New Haven, CT

Weiss, Carol H (with Michael Bucuvalas) 1980. Social Science Research and Decision-Making Columbia University Press, New York

Welch, Steve, J Gruhl and C Spohn 1984 Sentencing the influence of alternative measures of pnor record Criminology 22(2) $\cdot 215-218$

Zalman, Marvin, C Ostrom, P Gullıams and G Peaslee 1979 Sentencing in Michigan. Report of the Michigan Felony Sentencing Project State Court Administrative Office, Lansing, MI 